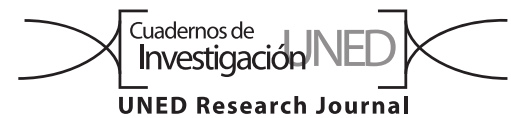

\title{
Yield, chemical composition and functional properties of essential oils from Mentha spicata (Lamiaceae) in Santiago del Estero, Argentina
}

\author{
Diego Ariel Meloni', Julia Andrea Lescano', María Paz Arraiza² \& Rosa Elizabeth Beltrán' \\ 1. Universidad Nacional de Santiago del Estero, Facultad de Agronomía y Agroindustrias. Av. Belgrano (S) 1912, Santiago del Estero, Argentina; \\ dmeloniunse@gmail.com; (D) http://orcid.org/0000-0001-9869-3455, \\ andlescano@yahoo.com.ar; (D) http://orcid.org/0000-0002-1960-9938, \\ rebeltran@unse.edu.ar, (D) http://orcid.org/0000-0002-8068-219X \\ 2. Universidad Politécnica de Madrid, ETSI Montes, Madrid, España; \\ paz.arraiza@upm.es, (D) http://orcid.org/0000-0002-7939-6647
}

Received 22-III-2018 • Corrected 27-V-2019 • Accepted 24-VI-2019

DOI: https://doi.org/10.22458/urj.v11i3.2624

\begin{abstract}
Introduction: Mentha spicata, commonly known as spearmint, is the most common and popular cultivated mint, and is used in food, perfumes and pharmaceutical products. Objective: To determine the yield, composition and properties of essential oil from M. spicata grown in Santiago del Estero, Argentina. Methods: We used steam distillation, gas chromatography and mass spectrometry to determine chemical composition, antioxidant activity and acetylcholinesterase inhibition. Results: Essential oil yield ranged from 0.8 to $1.3 \mathrm{~mL} \cdot 100 \mathrm{~g}^{-1}$ $\mathrm{DM}$. The main essential components were carvone $(60,72-68,09 \%)$, limonene (14,23-16,41\%), $\alpha$-pinene $(0,12-3,14 \%), \beta$-myrcene $(0,35-2,33 \%)$, 1,8 -cineole $(1,69-2,73 \%)$, cis-dihydrocarvone $(1,82-2,31 \%)$, trans-craveol $(1,09-1,19 \%), \beta$-bourbonene $(2,44-3,17 \%)$ and $\beta$-Caryophyllene $(1,42-1,82 \%)$. The oil had high antioxidant activity, with $I C_{50}$ values among 7,5-12,06 $\mu \mathrm{g} / \mathrm{mL}$ (DPPH method) and 26,94-38,14 $\mu \mathrm{g} / \mathrm{mL}$ ( $\beta$-carotene/linoleic acid method). It had good inhibition of acetylcholisterenase, with enzyme inhibition zones of 0,4-0,9 cm. Conclusion: The yield, quality and properties of the essential oil from $M$. spicata grown in Santiago del Estero meet market requirements.
\end{abstract}

Key words: Spearmint, essential oil, biological properties, antioxidant.

Mentha spicata (L.), ordinary known as spearmint, is a creeping rhizomatous, glabrous and herbaceus perennial plant, with a pungent smell. Today, there is a considerable activity and growing demand in Mentha cultivation because the commercial interest of its essential oil, which is among the ten most commercialized in the world (Chrysargyris, Xylia, Botsaris, \& Tzortzakis, 2017). The essential oil of Mentha species is widely used
RESUMEN: "Rendimiento, composición química, y propiedades funcionales de aceites esenciales de Mentha spicata (Lamiaceae) en Santiago del Estero, Argentina". Introducción: Mentha spicata, comúnmente conocida como "hierbabuena", es la menta más común y popular para cultivo, y se utiliza en la industria alimenticia, perfumería y farmacéutica. Objetivo: Determinar el rendimiento, composición y propiedades de los aceites esenciales de Mentha spicata, cultivada en Santiago del Estero, Argentina. Métodos: Usamos destilación a vapor, cromatogafía de gas y espectrometría de masa para determinar biomasa, rendimiento, composición química, actividad antioxidante y la inhibición de acetilcolinesterasa. Resultados: El rendimiento de aceites esenciales varió entre 0,8 y $1,3 \mathrm{~mL} \cdot 100 \mathrm{~g}^{-1} \mathrm{MS}$. Los principales aceites esenciales fueron: carvona $(60,72-68,09 \%)$, limoneno $(14,23-16,41 \%)$, a-pineno $(0,12-3,14 \%)$, $\beta$-mirceno $(0,35-2,33 \%)$, 1,8-cineol (1,69-2,73\%), cis-dihidrocarvona (1,82-2,31\%), trans-craveol $(1,09-1,19 \%)$, $\beta$-bourboneno $(2,44-3,17 \%)$ y $\beta$-cariofileno $(1,42-1,82 \%)$. El aceite presentó alta capacidad antioxidante, con valores de $\mathrm{IC}_{50}$ entre $7,5-12,06 \mu \mathrm{g} / \mathrm{mL}$ (método DPPH) y $26,94-38,14 \mu \mathrm{g} / \mathrm{mL}$ (método $\beta$-caroteno/ácido linoleico). Mostró una buena inhibición de la acetilcolinesterasa, con zonas de inhibición de la enzima de 0,4-0,9 cm. Conclusión: El rendimiento, calidad y propiedades del aceite esencial de $M$. spicata cultivada en Santiago del Estero, Argentina cumple con los requisitos del mercado.

Palabras clave: Hierbabuena, aceites esenciales, propiedades biológicas, antioxidante. in fragrance, spice and pharmaceutical industries. It is used as flavors in confectioneries, chewing gums, candies, liqueurs, drinks, cosmetic and other products (Zhao, Xu, Yang, Husaini, \& Wu, 2013). Additionally, spearmint on top of thyme, sage, rosemary and peppermint has been generally recognized as safe by US Food and Drug Administration (FDA) in a typical diet and can be safely consumed when used suitably (Yi \& Wetzstein, 2011). 
Many natural compounds extracted from plants have shown biological activities. Among the various types of compounds essential oils from aromatic and medicinal plants are receiving particular attention due to their antioxidant properties. Currently, the use of synthetic antioxidants in foods in order to prevent lipid oxidation is discouraged due to the carcinogenic potential, thus great effort has been taken place to investigate viable, safer natural antioxidants (Kumar \& Jnanesha, 2017).

Alzheimer's disease is associated with deficits in several brain neurotransmitters, such as acetylcholine, noradrenaline and serotonin, so it is suggested that a rise in the level of acetylcholine could be useful to improve signals of disease such as learning disability (Barros et al., 2015). Currently, acetylcholisterase (AChE) inhibitors have shown a greater efficiency in clinical treatment in Alzheimer's disease. Some of these have been found in plants (Dohi, Terasaki, \& Makino, 2009). Falé et al. (2013) also reports that $A C h E$ inhibitors can be used to increase gastrointestinal motility, since acetylcholine is the major excitatory neurotransmitter responsible for the peristaltic contractions. The results of these studies highlight the importance of the evaluation of AChE inhibitory activity of Mentha spicata essential oils since plants are used for treatment of gastrointestinal disturbances.

The cultivation of spearmint has significant potential in the Río Dulce irrigation area, in the province of Santiago del Estero, Argentina, where the environmental conditions are optimal for its development (Meloni et al., 2015). Although exploratory tests were previously conducted, there are no reports on the performance of the species in the region or the composition of its essential oil.

The objectives of the present study were analyze the yield chemical composition and functional properties of essential oils of Mentha spicata cultivated in Santiago del Estero, situated in Northwest Argentina.

\section{MATERIALS AND METHODS}

Plant materials: The crop was introduced on April 4,2014 , in the municipality of Villa Zanjón $\left(27^{\circ} 45^{\prime} \mathrm{S}\right.$, $64^{\circ} 18^{\prime} \mathrm{W}$ ), Santiago del Estero, Argentina, under irrigation.

The climate of the region is characterized as subtropical with a dry season, featuring in the late winter and early part of spring. During this season, there are dominant hot dry winds from the north sector, producing a great effect of evaporation, which increases the dryness of the air. The average rainfall is $550 \mathrm{~mm}$ per year, and the average maximum temperature $45^{\circ} \mathrm{C}$; the rapid rise in temperature in the spring, combined with the limited availability of soil water and the wind, result in an increased air saturation deficit (Meloni et al., 2015).

Irrigation was performed using the technique of flooding, which is the most commonly used by farmers in the region, with a water layer of $130 \mathrm{~mm}$. Regular monitoring of the phenology of the test was carried out, and when it reached $70 \%$ flowering, plants were harvested by hand at a height of $10 \mathrm{~cm}$, in order to simulate a commercial cut. The experimental unit consisted of plots of $36 \mathrm{~m}^{2}$, containing twenty tacks spaced at $0,60 \mathrm{~m}$. The experimental design was a randomized block with six replications, so the total area of the test was $216 \mathrm{~m}^{2}$. The results were analyzed with analysis of variance (ANOVA) and Tukey test.

Essential oil extraction: Samples were weighed and then dried in an oven with forced ventilation at $35^{\circ} \mathrm{C}$ to a constant weight, to determine the biomass production and partition (Zheljazkov, Cantrell, \& Astakie, 2010). Other samples were dried at room temperature (30$35^{\circ} \mathrm{C}$ ) to a constant weight, following the practice of local producers, and the total aerial part was ground for the extraction of essential oils. Essential oils were extracted by steam distillation using a 2-L Clevengertype apparatus at $60^{\circ} \mathrm{C}$, for 2,5 hours (Chauhan et al., 2009) and subsequent chemical analysis were made by gas chromatography (GC) and mass spectrometry (MS). The oils were recovered directly and were stored with anhydrous $\mathrm{Na}_{2} \mathrm{SO}_{4}$ in dark vials at $4^{\circ} \mathrm{C}$.

Identification of the oil components: GC/flame ionization detection (GC/FID) analysis was carried out using a PerkinElmer Claus 500 GC equipped with $30 \mathrm{~m} \times$ $0,32 \mathrm{~mm}$ Elite-5MS capillary columns $(0,32 \mu \mathrm{m}$ film thickness); $1 \mu \mathrm{L}$ of each sample was diluted with $300 \mu \mathrm{L}$ of Et2 $\mathrm{O}$ and injected $(0,5 \mu \mathrm{L})$ with a column temperature program of $40^{\circ} \mathrm{C}$ for 5 minutes, increased to $280^{\circ} \mathrm{C}$ at $4^{\circ} \mathrm{C} /$ minute and finally held at this last temperature for 10 minutes. Injector and detector were set at $250^{\circ} \mathrm{C}$ and $300^{\circ} \mathrm{C}$, respectively, and the carrier gas was He with a head pressure of $12,0 \mathrm{psi}$. GC-MS analyses were carried out using a Perkin- Elmer Clarus 500 GC equipped with a Clarus 500 MS using the same capillary column and chromatographic conditions as for the GC/FID analysis. Mass spectra were acquired over the 40-500amu range at 1 scan/second with ionizing electron energy of $70 \mathrm{eV}$, ion source $200^{\circ} \mathrm{C}$. The transfer line was set at $300^{\circ} \mathrm{C}$, carrier gas has He at $1,0 \mathrm{~mL} /$ minute. The identification of the oil components was performed by their linear retention indices (LRI), authentic reference compounds, peak matching library search and published mass spectra (Matraka 
et al., 2010). LRIs were calculated using an n-alkane series $\left(C_{6}-C_{32}\right)$ under the same $G C$ conditions as for the samples. All compounds were analytical standard grade. Anhydrous $\mathrm{Na}_{2} \mathrm{SO}_{4}$ was analytical reagent grade.

\section{Antioxidant activity of essential oils}

Determination of anti-free radical activity by 1,1-diphenil, 2-picrylhydrazyl (DPPH) method: The bleaching of the purple-colored solution of DPPH was used to determine radical scavenging activity according to Oke, Aslim, Ozturk \& Altundag (2009). Volume of $0,4 \mathrm{~mL}$ of serial essential oil dilutions $(0-100 \mu \mathrm{g} / \mathrm{mL})$ or of control sample (methanol) was mixed with $0,1 \mathrm{~mL}$ of $0,2 \mathrm{mMDPPH}$ solution in methanol. The mixture was shaken and then left in the dark for 30min. Absorbance was measured at $517 \mathrm{~nm}$. Butylated hydroxyl toluene (BHT) was used as a positive reference. DPPH radical scavenging activity was expressed as the inhibition percentage and was calculated using the equation: $I=100 *\left(A b_{\text {control }}-A b_{\text {sample }}\right) / A b_{\text {control }}$. $A b_{\text {control }}$ is the absorbance of the control and $A b_{\text {sample }}$ is the absorbance of the sample at $30 \mathrm{~min}$. Antiradical activity was expressed as $I C_{50}$ that is the concentration of the sample/reference that generates $50 \%$ of inhibition.

Assay of $\beta$-carotene/linoleic acid oxidation system: Antioxidant activity of the essential oils was also determined by the bleaching of $\beta$-carotene in linoleic acid system, by measuring the coupled autoxidation of $\beta$-carotene and linoleic acid (Znang, Chen, Wang, \& Yao, 2006). In brief, $5 \mathrm{mg}$ of $\beta$-carotene were dissolved in $50 \mathrm{~mL}$ of chloroform and $3 \mathrm{~mL}$ of that solution were added to 40 $\mathrm{mg}$ of linoleic acid and $400 \mathrm{mg}$ of Tween 20. Chloroform was removed with nitrogen gas and $100 \mathrm{~mL}$ of distilled water were added to emulsion and mixed well. Then, $1,5 \mathrm{~mL}$ of the emulsion was added to tube containing $20 \mu \mathrm{L}$ of the essential oil or BHT as a synthetic reference (using serial dilutions). Absorbance was measured immediately $(\mathrm{t}=0)$ at $470 \mathrm{~nm}$. The tubes were placed in water bath at $50^{\circ} \mathrm{C}$ for $60 \mathrm{~min}$ and the oxidation of the emulsion was measured again at $470 \mathrm{~nm}$. The antioxidant activity was expressed as inhibition percentage with reference to control $(20 \mu \mathrm{L}$ of methanol instead of EO) using the following equation AA (\%) $=100^{*}$ (DRc-DRs)/DRc. Where AA is antioxidant activity, DRc degradation rate of the control $=[\ln (a / b) / 60]$, DRs degradation rate of the sample $=$ $[\ln (\mathrm{a} / \mathrm{b}) / 60], \mathrm{a}=$ absorbance at $\mathrm{t}=0$ and $\mathrm{b}=$ absorbance at $\mathrm{t}=60 \mathrm{~min}$.

Acetylcholinesterase enzyme (AChE) inhibition: Inhibition of AChE was evaluated by TLC accordance with the methodology adapted by Rhee, Meent, Ingkaninan, $\&$ Verpoorte (2001). This bioassay consists in the application of the sample to TLC plates and spraying the plate with Ellman's reagent, with was prepared by mixing 5,5-dithiobis-2-nitrobenzoic acid (DTNB) and a buffer solution of acetylthiocholine iodide (ATCI). The TLC plate was subsequently sprayed with AChE $(3 \mathrm{U} / \mathrm{mL})$. After $3 \mathrm{~min}$, enzyme inhibition was observed by the presence of white spots on the yellow plate. The TLC enzyme test is basically quantitative but is still significantly sensitive. The following solutions were prepared for this test: (1) $50 \mathrm{mM}$ Tris- $\mathrm{HCl} \mathrm{pH} 8$ buffer; (2) $50 \mathrm{mM}$ Tris- $\mathrm{HCl} \mathrm{pH} 8$ containing $0,1 \mathrm{M} \mathrm{NaCl}$ and $0,02 \mathrm{M} \mathrm{MgCl}_{2} \cdot 6 \mathrm{H}_{2} \mathrm{O}$; (3) $1 \mathrm{mM}$ Ellman's reagent; and (4) $1 \mathrm{mM}$ ACTI. The lyophilized enzyme AChE was diluted in buffer solution (1) to prepare a $1000 \mathrm{U} / \mathrm{mL}$ enzyme solution. $5 \mu \mathrm{L}$ aliquots of compounds 1-7 $(4 \mathrm{mg} / \mathrm{mL})$ were initially applied to TLC plates (DCAlufolien, silica gel 60 F254, 0,2mm Merck). The plate was then sprayed with solutions 3 and 4 . After $3 \mathrm{~min}$, which is the time necessary for the solution to completely dry, the plate was sprayed with $\mathrm{AChE}(30 \mathrm{U} / \mathrm{mL})$. After approximately $10 \mathrm{~min}$, the appearance of white spots was observed and their diameters were immediately measured. Physostigmine was used as positive control.

Statistical analysis: The data were submitted to analysis of variance and the means were compared by the Tukey's Test at $\mathrm{p}<0,05$.

Ethical, conflict of interest and financial statements: The authors declare that they have fully complied with all pertinent ethical and legal requirements, both during the study and in the production of the manuscript; that there are no conflicts of interest of any kind; that all financial sources are fully and clearly stated in the acknowledgements section; and that they fully agree with the final edited version of the article. A signed document has been filed in the journal archives.

\section{RESULTS}

Three flowerings were registered during the vegetative cycle, being harvested on 20/Nov./2014, 2/Feb./2015 and 3/May/2015 (230, 305 y 394 days after the crop implantation). The aerial fresh biomass production in every cut was 14,88; 10,53 and 15,6t ha ${ }^{-1}$, and dry biomass 6,2 ; 5,03 and $5,27 \mathrm{t} \mathrm{ha}^{-1}$, respectively.

The yields of essential oils obtained in the three cuts

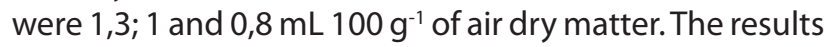
of characterization of the essential oils of spearmint are 
shown in Table 1. Twenty seven components were identified in the spearmint essential oils with greater content than $0,01 \%$, that represented $98,78-99,63 \%$ of the oils.

The main essential oils components were carvone $(60,72-68,09 \%)$, limonene $(14,23-16,41 \%)$, a-pinene $(0,12-3,14 \%), \beta$-myrcene $(0,35-2,33 \%), 1,8$-cineole $(1,69-$ $2,73 \%)$, cis-dihydrocarvone $(1,82-2,31 \%)$, trans-craveol $(1,09-1,19 \%), \beta$-bourbonene $(2,44-3,17 \%)$ and $\beta$-caryophyllene $(1,42-1,82 \%)$. Other components were found in content less than $1 \%$ in most cuts.

Several methods are used to define the antioxidant activity of essential oils, while DPPH and $\beta$-carotene/ linoleic assay are used mostly to quantify free radical scavenging activity. The evaluation of antioxidant activity and inhibition of acetylcholinesterase of essential oils from spearmint are shown in Table 2 . The results obtained with both methods show that the higher antioxidant capacity in the essential oils occurred in the first cut, with lower $I C_{50}$ decreasing in the other cuts.

The anticholinesterase activity of the essential oils also had fluctuations throughout the year (Table 2), with higher values in the cut done in spring, in relation to those effected in summer and autumn $(0,9 ; 0,7$ and 0,4 $\mathrm{cm}$ respectively).

\section{DISCUSSION}

The total aerial fresh biomass production was $41 \mathrm{t} \mathrm{ha}^{-1}$. This yield of fresh matter was much higher than that reported from Turkey by Telci, Sahbaz, Yilmaz, \& Tugay (2004), who studied the agronomic and chemical characteristics of M. spicata clones from different parts of the Turkish territory, with yields of $28 \mathrm{t} \mathrm{ha}^{-1}$ fresh weight, and 5,3 ha $^{-1}$ dry weigth. Telci \& Sahbaz (2005) also studied the yield of different species and procedences of Mentha genus in Turkey, having only two harvests in one year, observing a maximum yield in M. spicata of $36,4 \mathrm{t} \mathrm{ha}^{-1}$ fresh weight. On the other hand, fresh biomass production was lower than that obtained in different locations in Egypt, where values of $3 \mathrm{t} \mathrm{ha}^{-1}$ in Beni Suez, 49,8t ha-1 in Sohag, 47,1t ha-1 in Qena, and 43,5t ha-1 in Aswan (ElWahab \& Mohamed, 2009) were reported.

TABLE 1

Chemical composition (\%) of essential oil of spearmint (Mentha spicata L.)

\begin{tabular}{|c|c|c|c|c|c|}
\hline Component & $\mathrm{RI}_{\text {exp }}$ & $\mathrm{RI}_{\text {lit }}$ & First cut & Second cut & Third cut \\
\hline a-Pinene & 930 & 939 & $0,12 \mathrm{a}$ & $2,09 \mathrm{~b}$ & $3,14 c$ \\
\hline Sabinene & 970 & 975 & $0,63 a$ & $0,64 a$ & $0,63 a$ \\
\hline$\beta$-Pinene & 972 & 979 & $0,41 \mathrm{a}$ & $0,56 \mathrm{a}$ & $0,47 a$ \\
\hline$\beta$-Myrcene & 989 & 991 & $0,35 \mathrm{a}$ & $1,29 b$ & $2,33 \mathrm{c}$ \\
\hline$p$-cymene & 1022 & 1025 & $0,10 \mathrm{a}$ & $0,09 \mathrm{a}$ & $0,11 \mathrm{a}$ \\
\hline Limonene & 1026 & 1029 & $14,23 \mathrm{a}$ & $15,40 \mathrm{~b}$ & $16,41 \mathrm{c}$ \\
\hline 1,8- cineole & 1027 & 1031 & $2,73 \mathrm{a}$ & $2,08 \mathrm{~b}$ & $1,69 c$ \\
\hline Cis-Ocimene & 1037 & 1037 & $0,21 \mathrm{a}$ & $0,21 \mathrm{a}$ & $0,23 a$ \\
\hline Linalool & 1098 & 1097 & $0,49 a$ & $0,38 a$ & $0,42 \mathrm{a}$ \\
\hline 1-Octen-3-ol, acetate & 1112 & 1113 & $0,22 \mathrm{a}$ & $0,25 \mathrm{a}$ & $0,21 \mathrm{a}$ \\
\hline Borneol $+\delta$-Terpineol & 1165 & 1166 & $0,21 \mathrm{a}$ & $0,27 a$ & $0,35 a$ \\
\hline a-Terpineol & 1188 & 1189 & $0,61 \mathrm{a}$ & $0,67 a$ & $0,60 \mathrm{a}$ \\
\hline cis-dihydrocarvone & 1194 & 1193 & $1,82 \mathrm{a}$ & $1,79 a$ & $2,31 \mathrm{a}$ \\
\hline Trans-craveol & 1218 & 1217 & $1,09 a$ & $1,14 a$ & $1,19 a$ \\
\hline cis-carveol & 1228 & 1229 & $0,14 a$ & $0,36 b$ & $0,32 \mathrm{~b}$ \\
\hline Carvone & 1242 & 1243 & $68,09 \mathrm{a}$ & $6,41 b$ & $60,72 c$ \\
\hline p-Mentha-1,8-dien-3-one & 1270 & 1272 & $0,39 a$ & $0,40 a$ & $0,42 \mathrm{a}$ \\
\hline Carvacrol & 1299 & 1299 & $0,17 \mathrm{a}$ & $0,16 a$ & $0,14 a$ \\
\hline iso- Dihydrocarveol acetate & 1327 & 1329 & $0,21 \mathrm{a}$ & $0,18 \mathrm{a}$ & $0,19 a$ \\
\hline Piperitenone & 1339 & 1343 & $1,34 \mathrm{a}$ & $0,81 \mathrm{~b}$ & $0,42 \mathrm{c}$ \\
\hline$\beta$-Bourbonene & 1383 & 1388 & $2,44 \mathrm{a}$ & $3,12 b$ & $3,17 b$ \\
\hline$\beta$-Elemene & 1390 & 1391 & $0,59 a$ & $0,54 \mathrm{a}$ & $0,62 \mathrm{a}$ \\
\hline$\beta$-Caryophyllene & 1417 & 1419 & $1,49 a$ & $1,42 \mathrm{a}$ & $1,82 \mathrm{a}$ \\
\hline cis-Muurola-4(14),5 diene & 1451 & 1467 & $0,15 a$ & $0,12 \mathrm{a}$ & $0,14 a$ \\
\hline Germacrene D & 1479 & 1485 & $0,51 \mathrm{a}$ & $0,46 a$ & $0,39 \mathrm{~b}$ \\
\hline Bicyclogermacrene & 1494 & 1500 & $0,41 \mathrm{a}$ & $0,48 a$ & $0,43 a$ \\
\hline Germacrene A & 1503 & 1509 & $0,51 \mathrm{a}$ & $0,46 a$ & $0,39 \mathrm{~b}$ \\
\hline$\%$ Total identified & & & 99,63 & 98,78 & 99,26 \\
\hline
\end{tabular}

For each compound, values followed by different letters differ significantly by Tukey test at $5 \%$. $\mathrm{RI}_{\text {exp }}$ - experimental retention index; $\mathrm{RI}_{\text {lit }}$ - retention index of literature. 
TABLE 2

Total phenol, antioxidant capacities (IC $\mathrm{C}_{50}$ values) and inhibition of acetylcholinesterase of spearmint essential oils. Butylated hydroxyl toluene (BHT) and Physostigmine were used as a positive reference

\begin{tabular}{|c|c|c|c|}
\hline EO & $\mathrm{DPPH}_{\mathrm{IC}}(\mu \mathrm{g} / \mathrm{mL})$ & $\beta$-carotene/lineloic acid $I C_{50}(\mu \mathrm{g} / \mathrm{mL})$ & Inhibition AChE (cm) \\
\hline First cut & $7,25 \pm 0,21 a$ & $26,94 \pm 0,68 \mathrm{a}$ & $0,9 \mathrm{a}$ \\
\hline Second cut & $9,81 \pm 0,14 b$ & $30,01 \pm 1,01 b$ & $0,7 \mathrm{~b}$ \\
\hline Third cut & $12,06 \pm 0,12 c$ & $38,14 \pm 0,97 c$ & $0,4 \mathrm{c}$ \\
\hline BHT & $12,51 \pm 0,52 d$ & $70,55 \pm 2,15 d$ & - \\
\hline Physostigmine & - & - & $0,9 \mathrm{a}$ \\
\hline
\end{tabular}

The yields of essential oils obtained in the three cuts

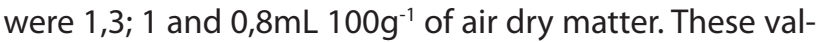
ues are within the range obtained by Bufalo et al. (2015) at Sheridan Research and Extension Center Experimental Fields (U.S.A). They are also similar to those obtained in the Iranian provinces of Ardestan, Saman and Kuhrang, where yields of 0,$5 ; 1,02$ and $1,54 \mathrm{~mL} 100 \mathrm{~g}^{-1}$ dry matter (Golpalvar \& Hadipanah, 2016), were reported. These are higher than those reported by Chauhan et al. (2009) in India which oscillated around $0,6 \%$. They are also significantly higher than those obtained by Barros et al. (2015) in the State of Ceará, Brazil, where the yield of essential oils in different sources of $M$. spicata ranged between 0,02 and $0,17 \%$. In spite of this, they were inferior to the yields obtained by Telci, Demirtas, Bayram, Arabaci, \& Kacar (2010) in the localities of Aydm, Bursa, Izmir and Tokat, Turkey, which were maintained in the intervals of 2,4 to $2,7 \%$.

Variations in quality and quantity of essential oils from aromatic plants are significantly influenced by intrinsic parameters, including species, chemotype / genotype, genetic structures, organogenesis and growth stages (Ghasemi Pirbalouti, Malekpoor, \& Salimi, 2017). In addition, external factors such as ecological and environmental conditions, including season climatic and soil conditions, extraction and drying methods had significant effects on the quality and quantity of the essential oils from aromatic plants (Grasemi Pirbalouti, Mahdad, \& Craker, 2013). In this case, the highest yields were obtained in cuts made in months with high average temperatures and long photoperiods. This observation coincides with the results obtained by other authors in species of the genus Mentha (Berti, Wllckens, Pastene, Fischer, \& Guerra, 2008; Telci et al., 2010).

In the current study, the spearmint essential oils were distinguished by the dominant presence of carvone, in agreement to previous studies, such as Chrysargyris et al. (2017) who found carvone content at 69,23\% in Cyprus, while Chaunan et al. (2009) and Scherer et al. (2013) found $76,6 \%$ and $67,1 \%$ in India and Brazil, respectively.
This is indicating that spearmint essential oils meet the requirements for medicinal applications, as the medical properties (i.e. stimulant, carminative and antispasmodic) of spearmint oils are preserved when carvone is greater than $51 \%$ while limonene is also present (Chrysargyris et al., 2017).

The percentage of carvone decreased, as lower temperatures and shorter photoperiods were recorded. An opposite trend was observed in limonene percentages. These results agree with those obtained by Telci et al. (2010), who studied the behaviour of a chemotype of M. spicata, in localities of Turkey, located at different altitudes, and therefore contrasting temperatures. These authors concluded that plants growing in less warm environments had a higher concentration of hydrocarbon monoterpenes, including limonene. On the other hand, according to Chrysargyris et al. (2017), limonene is a precursor of carvone, and interconversion of these compounds may have occurred, suggesting that it would be affected by climatic conditions (Kumar, Sharma, Sood, Agnihotri, \& Singh, 2013). Thus, the decrease in carvone concentrations observed in the cuts made during the months of February and March would be a consequence of their conversion to limonene. These results also agree with those reported by Bufalo et al. (2015) who studied the diurnal variations in carbon concentrations in spearmint. Carbon dioxide accumulated during the day, reaching a maximum concentration at 9:00PM. During the night, the concentration gradually decreased.

The contents of a-pinene varied throughout the year, with values similar to those reported by Chauhan et al. (2009) in India. Stations were also observed in compounds found in low concentrations compared to carvone and limonene ( $\beta$-myrcene, 1,8-cineole, cis-carveol, piperitenone, $\beta$-bourbonene, and germacrene $a)$.

The $\mathrm{IC}_{0}$ values obtained are in agreement with those reported in other studies. Dhif, Jelali, Mnif, Litaiem, \& Hamdi (2013) stated that $I_{50}$ of the essential oils of $M$. spicata grown in Tunisia was about $10 \mu \mathrm{g} / \mathrm{mL}$ (DPPH assay), being in agreement with the present findings. 
Chrysargyris et al. (2017) also obtained IC $C_{50}$ values within the range of 7,74; 12; 23 (DPPH method) and 27,65-36,58 ( $\beta$-carotene / linoleic acid method) in M. spicata grown in Cyprus under different doses of potassium fertilization. Essential oils compounds such as phenylpropanoids, monoterpenes, and oxygenated sesquiterpenes are capable to inhibit oxidation (Ouerghemmi et al., 2016). This interesting biological activity can be explained by the presence in our oil of monoterpenes limonene, 1,8-cineole, and carvone. In this sense, the seasonal changes in the sum of limonene; 1,8 -cineole and carvone $(85,05 \%$; $80,89 \%$ and $78,82 \%$ in the first, second and third cut, respectively) justify fluctuations in the antioxidant capacity of essential oils. The results obtained confirm previous reports about the importance of essential oils as natural antioxidants and their potent role in human health protection.

The anticholinesterase activity of the essential oils also had fluctuations throughout the year. Changes in anticholinesterase activity may be related to seasonal variations in limonene concentrations, and to the synergistic effect between majority and minority components, as suggested by Barros et al. (2015).

The high yield of essential oils and their high quality, given by the high contents of carvone and limonene, demonstrate that Mentha spicata can be grown in Santiago del Estero, Argentina, obtaining a product with the characteristics demanded by the market. Both the chemical composition and the properties of essential oils fluctuate throughout the year, with higher quality in spring and summer compared to autumn. The high antioxidant activity and anticholinesterase can also confer important therapeutic properties that should be tested in future works.

\section{REFERENCES}

Barros, A. S., Morais, S. M., Ferreiraa, P. A. T., Vieira, I. G. P., Craveiro, A. A., Fontenelle, R. O. S., Menezes, J. E. S. A., Silva, F. W. F., \& Sousa, H. A. (2015). Chemical composition and functional properties of essential oils from Mentha species. Industrial Crops and Products, 76, 557-564. DOI: 10.1016/j.indcrop.2015.07.004

Berti, M., Wilckens, R., Pastene, E., Fischer, S., \& Guerra, E. (2008). Yield and composition of Mentha x piperita L essential oil according to nitrogen fertilizer sources and rates in south-central Chile. Agro-Ciencia, 24, 58-71.

Bufalo, J., Zheljazkov, V. D., Cantrell, C. L., Astatkied, T., Ciampa, L., \& Jeliazkova, E. (2015). Diurnal effects on spearmint oil yields and composition. Scientia Horticulturae, 182, 73-76. DOI: 10.1016/j.scienta.2014.11.018
Chauhan, R. S., Kaul, M. K., Shahi, A. K., Kumar, A., Ram, G., \& Tawa, A. (2009). Chemical composition of essential oils in Mentha spicata L. accession [IIIM(J)26] from North-West Himalayan region, India. Industrial Crops and Products, 29, 654-656. DOI: 10.1016/j.indcrop.2008.12.003

Chrysargyris, A., Xylia, P, Botsaris, G., \& Tzortzakis, N. (2017) Antioxidant and antibacterial activities, mineral and essential oil composition of spearmint (Mentha spicata L.) affected by the potassium levels. Industrial Crops Products, 103, 202-2012. DOI: 10.1016/j. indcrop.2017.04.010

Dhifi, W., Jelali, N., Mnif, W., Litaiem, M., \& Hamdi, N. (2013). Chemical composition of the essential oil of Mentha spicata from Tunisia and its biological activities. Journal of Food Biochemistry, 37, 362-368. DOI: 10.1111/j.1745-4514.2012.00656.x

Dohi, S., Terasaki, M., \& Makino, M. (2009). Acetylcholinesterase inhibitory activityand chemical composition of commercial essential oils. Journal of Agricultural and Food Chemistry, 57, 4313-4318. DOI: 10.1021/jf804013j

El-Wahab, A., \& Mohamed., A. (2009). Evaluation of spearmint (Mentha spicata L.) productivity grown in different locaties under upper Egypt conditions. Research Journal of Agriculture and Biological Scince, 5, 250-254.

Falé, P. L., Ferreira, C., Rodrigues, A. M., Cleto, P., Madeira, P. J. A., Florêncio, M. H., Frazão, F. N., \& Serralheiro, M. L. M. (2013). Antioxidant andanti-acetylcholinesterase activity of commercially available medicinal infusions after in vitro gastrointestinal digestion. Journal of Medical Plants Research, 7, 1370-1378. DOI: 10.5897/JMPR13.4438

Ghasemi Pirbalouti, A., Mahdad, E., \& Craker, L. (2013). Effects of drying methods on qualitative and quantitative properties of essential oil of two basil landraces. Food Chemistry, 141, 2440-2449. DOI: 10.1016/j.foodchem.2013.05.098

Ghasemi Pirbalouti, A., Malekpoor, F., \& Salimi, A. (2017). Chemical composition and yield of essential oil from two Iranian species of basil (Ocimum ciliatum and Ocimum bacilicum). Trends in Phytochemical Research, 1, 3-8.

Golparvar, A. R., \& Hadipanah, A. (2016). Diversity in chemical composition and yield of essential oil from two Mentha species. Genetika, 48, 1101-1110. DOI: 10.2298/ GENSR1603101G

Kumar, R., Sharma, S., Sood, S., Agnihotri, V. K., \& Singh, B. (2013). Effect of diurnal variability and storage conditions on essential oil content and quality of damask rose (Rosa damascena Mill.) flowers in north western Himalayas. Scientia Horticulturae, 154, 102-108. DOI: 10.1016/j. scienta.2013.02.002

Kumar, A, \& Jnanesha A. C. (2017) Potential species of aromatic plants for cultivation in semi-arid tropical (Sat) regions of Deccan region. Journal of Medicinal Plants Studies, 5, 269-272.

Matraka, M. M., Ninou, E., Ginnakoula, A., Lazari, D, Filotheou, H. P., \& Bosabalidis, A. M. (2010). Effects of soil water 
contente on Mentha spicata L. and Origanim dictamnus L. Israel Journal Plant Science, 58, 229-239. DOI: 10.1560/ IJPS.58.2.229

Meloni, D. A., Arraiza, M. P., Garay, F., Silva, D. M., Abdala, G., David, R. N., López, J., \& Beltrán, R. (2015). Biomass and essential oil yields of cornmint (Mentha arvensis L.) grown in the irrigation area of Río Dulce, Santiago del Estero, Argentina. Journal of Essential Oil Research, 7, 148-152. DOI: 10.1080/10412905.2014.990642

Oke, F., Aslim, B., Ozturk, S., \& Altundag, S. (2009). Essential oil composition, antimicrobial and antioxidant activities of Satureja cuneifolia Ten. Food Chemistry, 112, 874-879. DOI: 10.1016/j.foodchem.2008.06.061

Ouerghemmi, S., Sebei, H., Siracusa, L. Ruberto, J., Saija, A., Cimino, F., \& Cristani, M. (2016). Comparative study of phenolic composition and antioxidant activity of leaf extracts from three wild Rosa species grown in different Tunisia regions: Rosa canina L., Rosa moschata Herrm. and Rosa sempervirens L. Industrial Crops and Products, 94, 167-177. DOI: 10.1016/j.indcrop.2016.08.019

Rhee, I. K., Meent, M. V., Ingkaninan, K., \& Verpoorte, R. (2001). Screening for acetylcholinesterase inhibitors from Amaryllidaceae using silica gel thin-layer chromatography in combination with bioactivity staining. Journal of Chromatography A., 1-2, 217-223. DOI: 10.1016/ S0021-9673(01)00624-0

Scherer, R., Lemos, M. F., Lemos, M. F., Martinelli, G. C., Martins, J. D. L., \& da Silva, A. G. (2013). Antioxidant and antibacterial activities and composition of Brazilian spearmint (Mentha spicata L.). Industrial Crops Products, 50, 408413. DOI: $10.1016 /$ j.indcrop.2013.07.007
Telci, I., \& Sahbaz, N. (2005). Variation of yield, essential oil and carvone contents in clones selected from carvone-scented landraces of Turkish Mentha species. Journal of Agronomy, 4, 96-102. DOI: 10.3923/ja.2005.96.102

Telci, I, Demirtas, L., Bayram, E., Arabaci, O., \& Kacar, O. (2010). Environmental variation on aroma components of pulegone/piperitone rich spearmint (Mentha spicata L.). Industrial Crops and Products, 32, 588-592. DOI: 10.1016/j. indcrop.2010.07.009

Telci, I, Sahbaz, N.,Yilmaz, G., \&Tugay, M. (2004). Agronomical and chemicalcharacterization ofspearmint(MenthaspicataL.) originating in Turkey. Economic Botany, 58, 721-728. DOI: 10.1663/0013-0001(2004)058[0721:AACCOS]2.0.CO;2

Yi, W., \& Wetzstein, H. Y. (2011). Anti-tumorigenic activity of five culinary and medicinal herbs grown under greenhouse conditions and their combination effects. Journal of the Science of Food and Agriculture, 91, 1849-1854. DOI: 10.1002/jsfa.4394

Zhang, H., Chen, F., Wang, X., \& Yao, H. (2006). Evaluation of antioxidant activity of parsley (Petroselinum crispum) essential oil and identification of its antioxidant constituents. Food Research International, 39, 833-839. DOI: 10.1016/j.foodres.2006.03.007

Zhao, D., Xu, Y. W., Yang, G. L., Husaini, A. M., \& Wu, W. (2013). Variation of essential oil of Mentha haplocalyx Briq. And Mentha spicata L. from China. Industrial Crops and Products, 42, 251-260. DOI: 10.1016/j. indcrop.2012.06.010

Zheljazkov, V. D, Cantrell, C. L., \& Astakie, T. (2010). Yield and composition of oil from Japanese cornmint fresh and dry material harvested successively. Agronomy Journal, 102, 1652-1656. DOI: 10.2134/agronj2010.0234 